\title{
Methods and Schemes of Opening-up the Quarry Fields at Various Bedding Conditions of Deposits
}

\author{
Kolesnikov Valery F \\ T. F. Gorbachev Kuzbass State Technical University, \\ Kemerovo, Russian Federation. \\ tma.geolog@kuzstu.ru
}

\begin{abstract}
The notion of opening-up, i.e. creation of conditions for cargo traffic in a mine operation moving the cargo from the face to the place of its reception within the boundaries of the mine or outside, means the same whether it is an open-pit mine, a quarry or an underground mine.

However, in open cast mining, the term "opening-up" is often understood as stripping or making an initial cut at the contact with minerals, as there is no clear definition of the concepts of the method of opening, opening schemes, and opening systems.

Having studied various options used to classify the methods of opening, we offer to emphasize those methods which show how the opening-up is implemented (by mine workings or without them), and all other descriptions should be attributed to the schemes, since they show the spatial position of the method (external, internal, individual, group workings, etc.)
\end{abstract}

Keywords - open pit mining, initial cut, method of opening, scheme of opening.

\section{INTRODUCTION}

In recent decades, the periodical literature on open cast mining mostly cover the issues aimed at solving specific technical problems, including various case-studies [1-9]. Also, considerable attention is paid to geo-ecology of open pit mining [10-14], and to economic problems in mining $[15,16]$. However, there is a distinct lack of theoretical works, first of all, it concerns modernization and adaptation of existing classifications, concepts and definitions related to open pit mining applied to current conditions. In addition, there are often discrepancies in some terms and definitions. Therefore, this article, in our opinion, is highly relevant.

The concept of "opening" in the open cast mining should include a clear definition of its purpose, method of implementation and schemes of presentation. Developing the theory of overburden freight traffic in the quarry, Academician V.V. Rzhevsky identified that it was the freight traffic that determined the decision of opening up the quarry field and that the opening-up was closely linked to the method of mining. At the same time, he highlighted the specific features of opening up the stripping and mining benches during the quarry operation [17].

\section{MATERIALS AND METHODS}

Open pit mining within the boundaries of the quarry field is carried out in accordance with the adopted system of development that determines the order of development, stripping and mining operations. This order should ensure the implementation of the specified production capacity of the quarry by production of minerals and the appropriate volumes of overburden (Fig. 1).

Fig. 1: $\mathrm{O}_{\mathrm{fpm}}-$ overburden that is removed at the first phase of mining; $\mathrm{C}_{\mathrm{fpm}}-$ coal that is removed at the first phase of mining; $\gamma_{\mathrm{m} . \mathrm{f}}$ and $\gamma_{\mathrm{n} . \mathrm{f}}-$ overall slope angle on mining and nonmining flanks of the open pit, respectively; $\alpha_{\mathrm{s}}-$ angle of coal bedding. The arrows indicates the direction of development of mining operations.
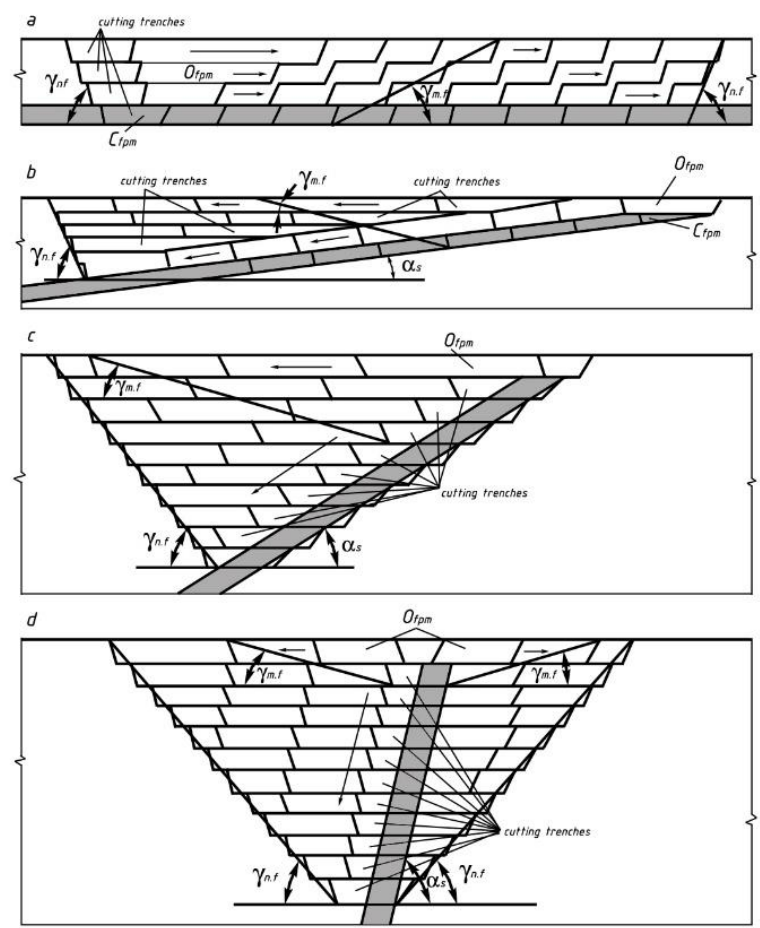

Fig. 1. Directions of development of open pit mining for various conditions of fields bedding: $\mathrm{a}$ - horizontal seam; $\mathrm{b}$ -

flat seam; c - inclined seam; $d$ - steep seam.

The formed stripping and mining freight traffic determines the set of equipment that must comply with the conditions of seam bedding in the developed deposit, as well as the order of preparatory, stripping and mining operations; therefore, they define the system of mining, in accordance with the classification by V.V. Rzhevsky [17]. 
The specific features of the development of mining operations and the formation of stripping freight traffic determined the division of mineral deposits developed by open pit mining by the dip angle into the horizontal, flat, inclined and steep deposits (Fig. 2).
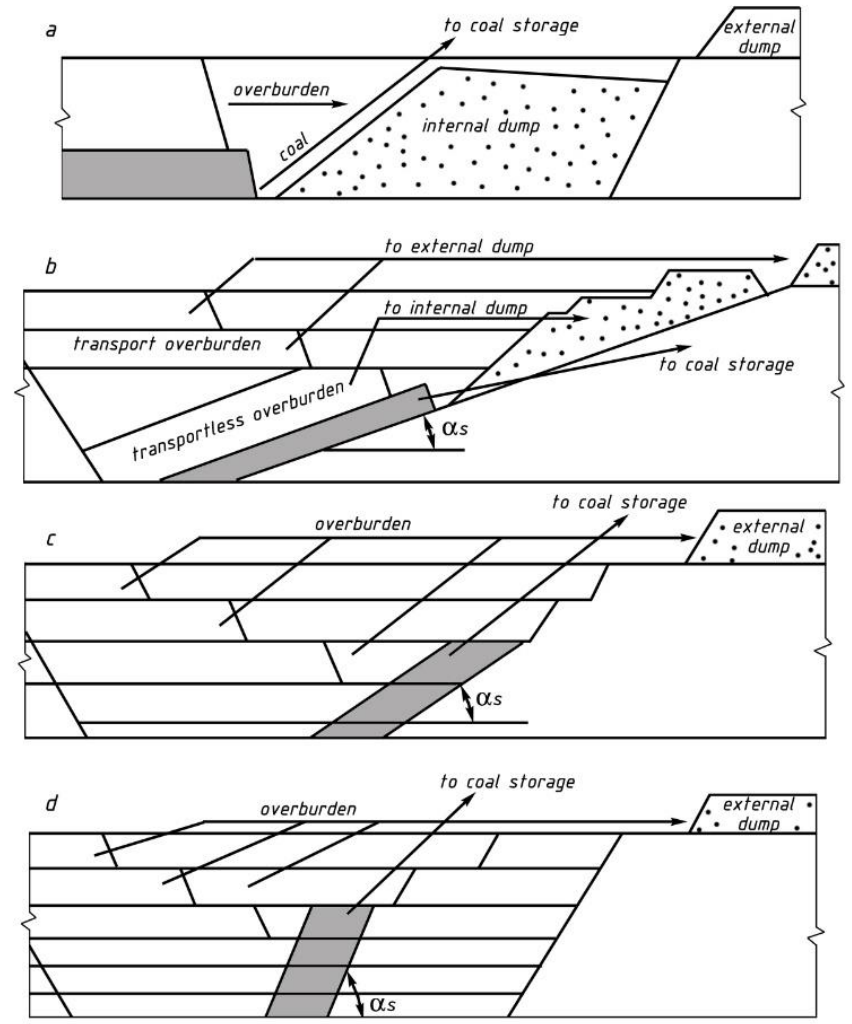

Fig. 2. Quarry freight traffic schemes at various angles of dip: $a-0-5^{\circ}, b-6-14^{\circ}, c-15-45^{\circ}, d-46-90^{\circ}$.

\section{RESULTS}

Horizontal deposits are the seams with dip angles from 0 to $5^{\circ}$, which will be developed within the established quarry boundaries with the removal of overburden only from the hanging wall side and complete placement of rocks during the operation of the quarry in the mined-out space as the seam is excavated, where the overburden is moved by excavators or motor transport.

The ultimate value $5^{\circ}$ of the dip angle is determined by the possibility of direct access of the vehicle to the bench by the seam floor, since it corresponds to the ruling gradient of $80 \%$.

Flat deposits are the seams with dip angles from 6 to $14^{\circ}$, which will be developed within the established quarry boundaries with the removal of overburden only from the hanging wall side, and placing it during the quarry operation partially in the mined space using draglines by direct dumping, and the rest of the overburden will be transported to internal or external dumps.

The limit value of the dip angle $14^{\circ}$ is determined by the stable placement of the internal dumps on the seam floor without additional measures.
Inclined deposits are the seams with dip angles from 15 to $45^{\circ}$, which will be developed within the established quarry boundaries with the excavation of overburden only from the hanging wall side and the rock will be completely moved to external dumps.

The limit value of the dip angle of $45^{\circ}$ is determined by stable position of non-mining flank of opencast with hard rocks.

Steep deposits are the seams with dip angles from 46 to $90^{\circ}$, which will be developed within the established quarry boundaries with the removal of overburden from both hanging and lying walls of the seam and the rocks will be completely moved to external dumps.

\section{DISCUSSION}

The quarry overburden traffic has different directions at various conditions of fields bedding. Mineral product in all cases is transported to the preparation plant or to coal storage. The operation of all these freight traffic directions is provided for by one or another method of opening.

Method of opening is the creation of conditions for transporting of material from the working levels of the quarry via open-cut workings (trench method) or underground mine workings (underground method), as well as using excavation equipment, and special structures (special method).

The classification of opening methods by the presence and type of openings (or their absence) is presented in Table 1.

TABLE 1. Classification of opening methods

\begin{tabular}{|c|c|}
\hline Opening method & Essence of the opening method \\
\hline Trench & $\begin{array}{c}\text { Opening by a system of open-cut } \\
\text { workings }\end{array}$ \\
\hline Underground & $\begin{array}{c}\text { Opening by a system of underground } \\
\text { workings }\end{array}$ \\
\hline Special & $\begin{array}{c}\text { Opening by a system of mining } \\
\text { equipment, special structures }\end{array}$ \\
\hline Combined & $\begin{array}{c}\text { Opening by a combination of various } \\
\text { methods, such as trench and special; } \\
\text { trench and underground; underground } \\
\text { and special; special, trench and } \\
\text { underground }\end{array}$ \\
\hline
\end{tabular}

As can be seen from the table, each method is the opening system that ensures operation of freight traffic at the quarry levels.

It is therefore proposed to consider that the purpose of opening is to establish communication of working levels' freight traffic with places of freight acceptance inside the quarry and beyond its boundaries.

The opening method shows how the working levels are opened up, and the scheme shows how the material is moved in the area at one or another method in a particular period of quarry operation.

Thus, the essence of the opening method is expressed through the opening system. 
The opening systems in open cast mining are sets of incline trenches and semi-trenches, steep trenches, underground mine workings (crosscuts, tunnels, inclined shafts, adits) interconnected by transport network and ensuring the conditions for transportation of minerals from the faces to their place of storage; a set of excavating machinery carrying out excavation and re-handling of overburden under direct dumping scheme; excavators in combination with special structures for belt conveyors ensuring rock mass transportation; special structures (dams, viaducts, embankments, berms) to direct the freight traffic from the face to the storage places (Fig. 3).

Opening systems have various spatial development in different periods of the quarry operation depending on the method of opening, types of transport, parameters of mining enterprises and other conditions.

Thus, variants of the spatial development of the working levels freight traffic are the essence of quarry opening schemes and depend on such factors as the methods of opening, conditions for opencast mining, system of mining, etc.

We propose the following definition: the opening scheme is a description or graphic representation of opening systems' spatial location of a one or another opening method in a certain period of the quarry operation.

The opening scheme is a qualitative characteristic of a quarry in a specific period of its exploitation, and reflects the parameters of freight traffic corresponding to a given production facility, the parameters of opening workings and equipment, ensuring the operation of this traffic. Therefore, it is the scheme of one or another opening method that should be the object for selection of the rational option.

The main attributes underlying the quarries opening schemes are the ways of creating conditions for freight traffic, which are expressed by the presence or absence of mine workings, construction, equipment. The type of opening workings, designs and constructions is the basic opening scheme depending on mining conditions (Table 2).
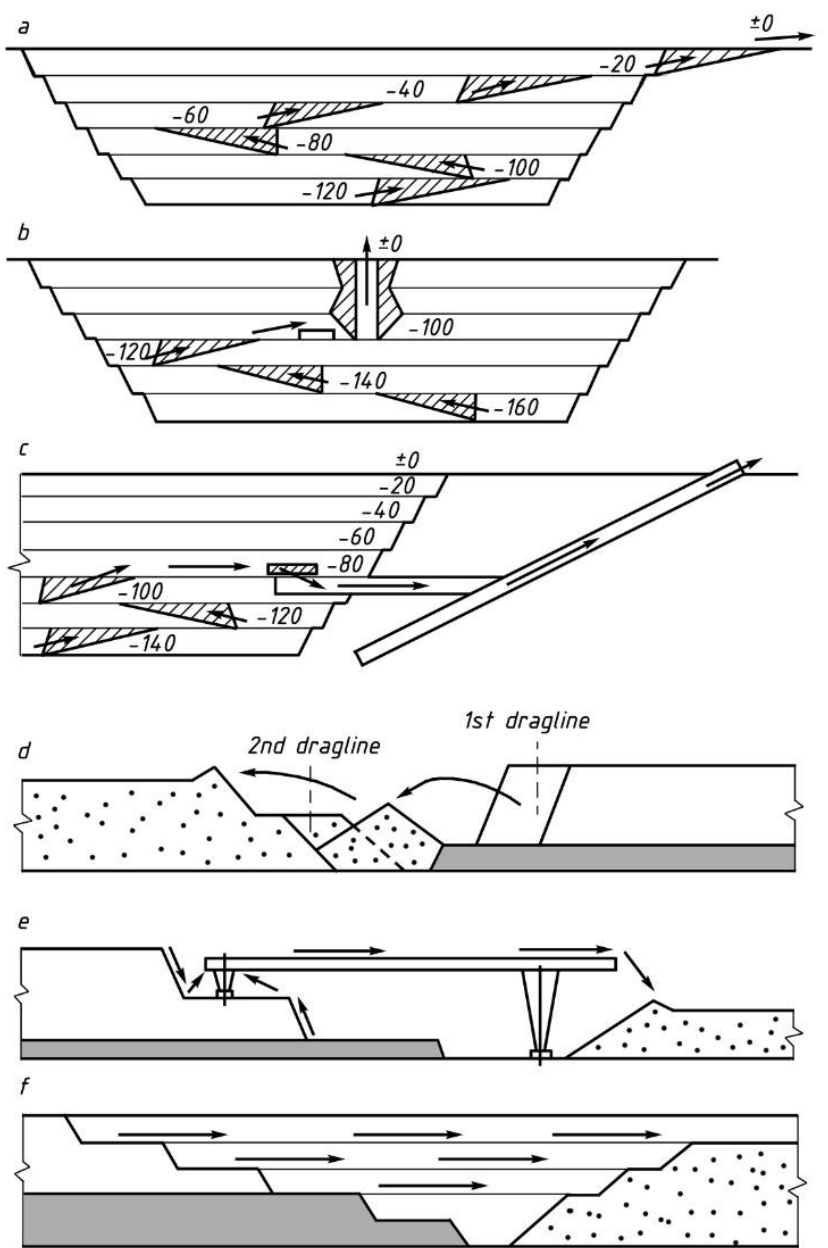

Fig. 3. Opening-up systems of: trench $(a, b)$, trench-mine (c) and special opening methods $(\mathrm{d}, \mathrm{e}, \mathrm{f})$.

TABLE 2. Interconnection of methods and basic schemes of career working levels opening

\begin{tabular}{|c|c|c|c|c|c|c|}
\hline \multirow{2}{*}{\multicolumn{3}{|c|}{ Conditions of use }} & \multicolumn{4}{|c|}{ Opening methods of quarry levels } \\
\hline & & & trench & underground & special & combined \\
\hline \multicolumn{2}{|c|}{ Upland quarry levels } & \multirow{5}{*}{ 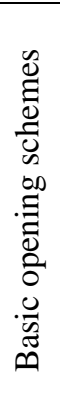 } & $\begin{array}{c}\text { Direct entries, inclined } \\
\text { semi-trenches and trenches, } \\
\text { steep trenches (ore rolls) }\end{array}$ & $\begin{array}{c}\text { Tunnels, } \\
\text { galleries with the } \\
\text { ore passes }\end{array}$ & $\begin{array}{l}\text { Excavators, rope } \\
\text { constructions }\end{array}$ & \multirow{5}{*}{ 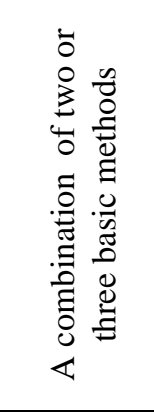 } \\
\hline \multirow{4}{*}{ 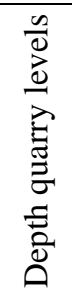 } & $\begin{array}{c}\text { Horizontal } \\
\text { seam }\end{array}$ & & $\begin{array}{l}\text { Direct entries, inclined } \\
\text { trenches }\end{array}$ & \multirow{2}{*}{$\begin{array}{l}\text { Tunnels under } \\
\text { internal dumps }\end{array}$} & \multirow{2}{*}{$\begin{array}{c}\text { Excavators, conveyor } \\
\text { systems, } \\
\text { embankments, } \\
\text { blasting }\end{array}$} & \\
\hline & Flat seam & & Inclined trenches & & & \\
\hline & Inclined seam & & \multirow{2}{*}{$\begin{array}{l}\text { Inclined trenches, steep } \\
\text { trenches }\end{array}$} & \multirow{2}{*}{$\begin{array}{l}\text { Shafts with } \\
\text { crosscuts }\end{array}$} & \multirow[b]{2}{*}{$\begin{array}{l}\text { Draglines, } \\
\text { embankments }\end{array}$} & \\
\hline & Steep seam & & & & & \\
\hline
\end{tabular}


The rational opening scheme is determined, in the first place, by a rational way to move the material of quarry benches to places of their storage in accordance with the volume and directions of freight traffic.

Dependence of the methods and schemes of quarries' opening on the parameters of the main freight flows is determined by technical parameters of options, which include number of mining and transportation equipment, options and volumes of the opening workings, and others. These indicators are the starting values of economic calculations to select the effective variant.

Systematization of the main factors that determine the method and scheme of opening, and independent attributes that characterize the spatial development of load traffic in a specific period of exploitation, field observations and research of excavation, transportation and dumping machines, systematization of technological schemes and load traffic at the lateral and transverse development of the front of mining operations have provided the basis to develop the scientific and methodological principles for the calculation of technical parameters of opening schemes and economic indicators with the justification of the options for opening up of the quarry working levels.

The analysis of open pit mining and formation of load flows at the lateral and transverse mining systems applied to the conditions of various deposits shows a wide variety of schemes of any opening method reflecting the shape of the process, as well as all the possible methods of opening that reflect its kind (the content).

In the development of the depth type horizontal deposits, opening of rock benches is carried out by direct entries on a relief and by draglines that re-handle the overburden in a goaf. Opening of coal benches is carried out by sloping trenches with the creation of the transport lanes, usually on the floor of the worked-out seam in the zone of internal waste dumps.

In the development of the upland-depth type flat deposits, opening of transport benches in the upland part is carried out by direct entries on a relief or by inclined semi-trenches. Transport benches of the depth part are opened by inclined trenches.

Opening of rock benches that being handled by nontransport scheme is carried out by the dragline excavators. The coal seam at transportless stripping is opened by inclined trenches on the mining flank or by inclined semi-trenches that are cut on the seam floor in the internal dumps zone.

In developing of the depth type inclined seams, opening of working benches is carried out by inclined trenches.

Opening of working benches of an upland-depth type is carried out by inclined seams, carried out by direct entries and by earth-fill to the levels of the upland, and by inclined trenches to the depth part benches.

In developing of the depth type steep fields, opening is carried out by inclined and steep trenches.

\section{CONCLUSION}

Given the considered experience of opening up the working benches of coal and ore pits, it should be noted the possibility of using underground mine workings at open-pit mining in the development of the depth type horizontal, flat and inclined seams and for upland horizons of upland-depth type deposits.

It is also possible to arrange freight traffic using the skip hoists and aero-geotechnical complexes.

All this confirms the conclusions that the main attributes underlying the quarries opening schemes are methods of creating conditions for freight traffic which are expressed by the presence or absence of mining workings, structures, and equipment. The type of opening-up workings and structures is the basic opening scheme depending on the mining conditions.

\section{REFERENCES}

[1] Rzhevsky V.V. (1977). Open Mining Processes [in Russian], Nedra, Moscow.

[2] Belyakov Y.I. (1977). Improvement in Excavation and Loading at Quarries [in Russian], Nedra, Moscow.

[3] Trubetskoy K.N. (1989). Science of loading machine application to open mining. Synopsis of Dr. Eng. Thesis [in Russian], Moscow.

[4] Biryukov A.V., Kuznetsov V.I., Tashkinov A.S. (1996). Statistical Models in Mining Processes [in Russian], Kuzbassvuzizdat, Kemerovo.

[5] Belyakov Y.I. (1987). Excavation and Loading at Open Pits [in Russian], Nedra, Moscow.

[6] Shchadov M.I., Vinnitski K.E., Potapov M.G. (1969). Development of the Machinery and Technology for Open Coal Mining [in Russian], Nedra, Moscow

[7] Vasil'ev E.I., Kolesnikov V.F. (1969). Technical-economic bases of schemes for opening up open-pit fields during the working of inclined and steeply-dipping deposits. Soviet Mining, 5(5), 532-541.

[8] Bereznyak M.M., Kalinin A.V., Pronoza V.G. (1970). A method of calculating the width of the caved rubble in the transportless system of working a series of sloping beds. Soviet Mining, 6(6), 638-643.

[9] Lokhanov B.N., Zakharov Yu.A., Bereznyak M.M., Kalinin, A.V. (1967). Open-cut mines in the Kuzbass: Progress and prospects. Soviet Mining, 3(5), 523-527.

[10] Tyulenev M., Zhironkin S., Litvin O. (2015). The low-cost technology of quarry water purifying using the artificial filters of overburden rock. Pollution Research, 34(4), 825-830.

[11] Tyulenev M., Zhironkin S., Kolotov K., and Garina E. (2016). Background of innovative platform for substitution of quarry water purifying technology. Pollution Research, 35(2), 221-226.

[12] Lesin Y.V., Lukyanova S.Y. and Tyulenev M.A. (2010). Mass transfer of dispersed particles in water filtration in macro-grained media. Journal of Mining Science, 46(1), 78-81.

[13] Lesin Y.V., Lukyanova S.Y., and Tyulenev M.A. (2015). Formation of the composition and properties of dumps on the open-pit mines of Kuzbass. IOP Conference Series: Materials Science and Engineering, 91(1), 012093.

[14] Tyulenev M., Lesin Y., Zhironkin S. and Garina E. (2016). Coal producers waste water purification. Metallurgical and Mining Industry, 2, $52-56$.

[15] Zhironkin S.A. (2001). Governmental factoring development of TEK Kuzbass. Ugol', 6, 62.

[16] Zhironkin S.A. (2002). Prospects and new possibilities investment attracting to Kuzbass coal mining industry. Ugol', 6, 31-36.

[17] Rzhevsky V.V. (1985). Open Mining [in Russian], Nedra, Moscow. 